\title{
ENERGY MIX AS THE BASIC REGULARITY OF THE PRINCIPLES OF SUSTAINABLE DEVELOPMENT
} DOI: $10.22616 / E S R D .2019 .144$

\author{
Ireneusz Miciula ${ }^{1}$, Ph.D. \\ ${ }^{1}$ University of Szczecin, Faculty of Economics and Management, Institute of Finance
}

\begin{abstract}
Energy sources are a basic factor of economic development. Within the framework of the climate and energy policy of the European Union (EU), the rural areas that allow the use of renewable energy sources become more important. The aim of the article is to show the direct impact of contemporary EU policy in this area on the economic situation of states. At the same time, we are developing recommendations for the EU regarding future climate and energy policy by analysing empirical data developed by the world's largest organizations and institutions, such as the International Atomic Energy Agency, the World Nuclear Association, Eurostat and the International Energy Agency, and practices used by EU countries. The basis of the presented considerations and recommendations is a review of the subject literature and statistical analysis of empirical data. Conclusions are presented in accordance with the economic effectiveness of various energy sources and the principles of sustainable development.
\end{abstract}

Key words: EU energy and climate policy, energy sources, economic effectiveness, renewable energy sources. JEL code: $A 11, C 82$, F5, F63, N5, O11, Q01, Q43.

\section{Introduction}

Energy mix is a combination of various types of energy production and consumption. Their diversity, i.e. various ways of generating and using energy, increases the security of a country in the event of a failure or depletion of one of the sources. The energy market operates according to economic rules, hence the possibility of choosing a source of energy, which undoubtedly contributes to an increase in competitiveness and a decrease in prices for end users. By promoting domestic energy resources, a country does not have to rely on energy imported from other countries, which has a number of economic and social advantages. Energy is supplied in the form of electricity, heat and fuel for operating machines and devices. In the case of electrical energy, primary energy produced from a particular source is processed so that it can be used and delivered to end users via an energy transmission grid. The case is similar with thermal energy, but a greater number of alternative sources of energy may be used for production, including regional resources, and its processing and transmission are less complex.

Access to energy sources undoubtedly constitutes one of the basic factors of economic development. Europe is increasingly dependent on oil and gas imports, with a constantly growing demand for these raw materials. Therefore, the problem is the lack of diversification of energy sources, as well as the issue of security of its supply, directly related to the dimension of external EU activities. At the same time, there is a need for Member States to build competitive internal energy markets and increase energy efficiency. In addition, the Union responds to global problems that arise from climate change. Undoubtedly, all EU countries want to pursue the goal of reducing $\mathrm{CO}_{2}$ emissions. However, they differ in how they should be achieved. First of all, the strategy of limiting negative climate change must be effective globally and cannot significantly limit economic development and the well-being of societies. Therefore, as part of the EU's climate and energy policy, priority should first be given to the objectives to be achieved in the first place, since all tasks in the short term until 2030 cannot be achieved, including due to the limited resources. The nature of challenges in the sphere of energy security creates an unprecedented platform for enhanced cooperation and co-shaping the EU's climate and energy policy. The EU strategy consisting in the 
diversification of energy sources will contribute to the development of competition and will allow to take into account environmental protection requirements, and will also be the reason for balancing the interests of energy companies and energy consumers. However, attention should also be paid to the limitations and reality of EU plans for individual countries and the economic consequences that may occur as a result of introducing unfavourable processes forced by the EU. The impact of such activities on the functioning of economic entities will be huge. Therefore, it is necessary to take care of activities that will allow for the sustainable development of all EU member states and ensure energy security in a manner that will be based on the principles of rational and effective use of energy resources.

\section{Research results and discussion}

The charts below (Figure 1 and Figure 2) analyse electrical energy mix around the world and in EU countries and specify the main sources of energy in this category.

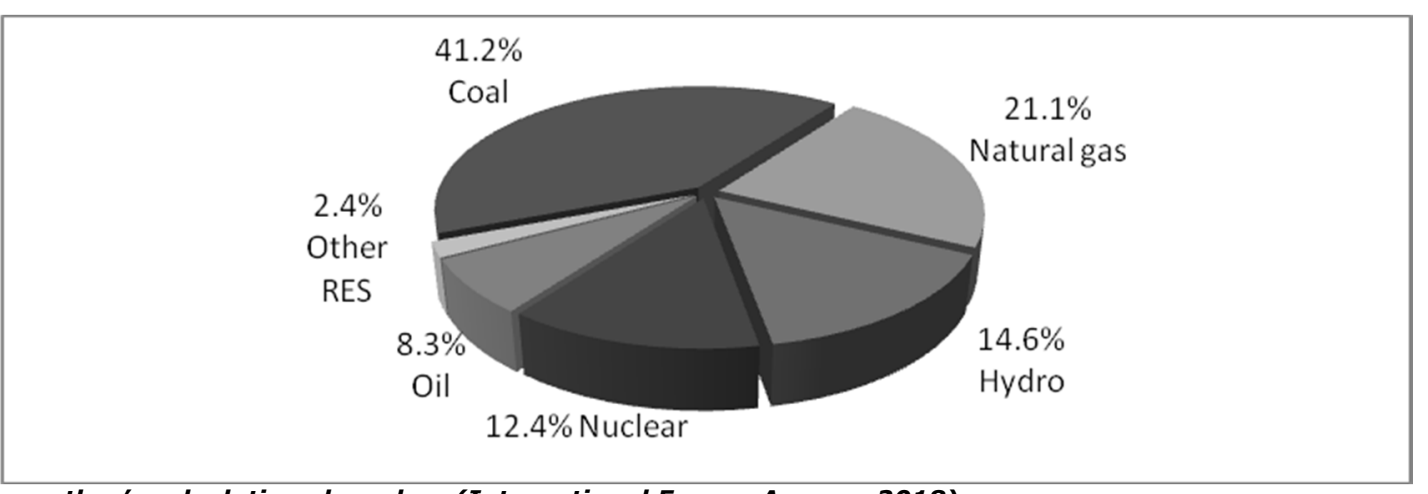

Source: author's calculations based on (International Energy Agency, 2018)

Fig. 1. Global production of electrical energy in 2016 (in percent)

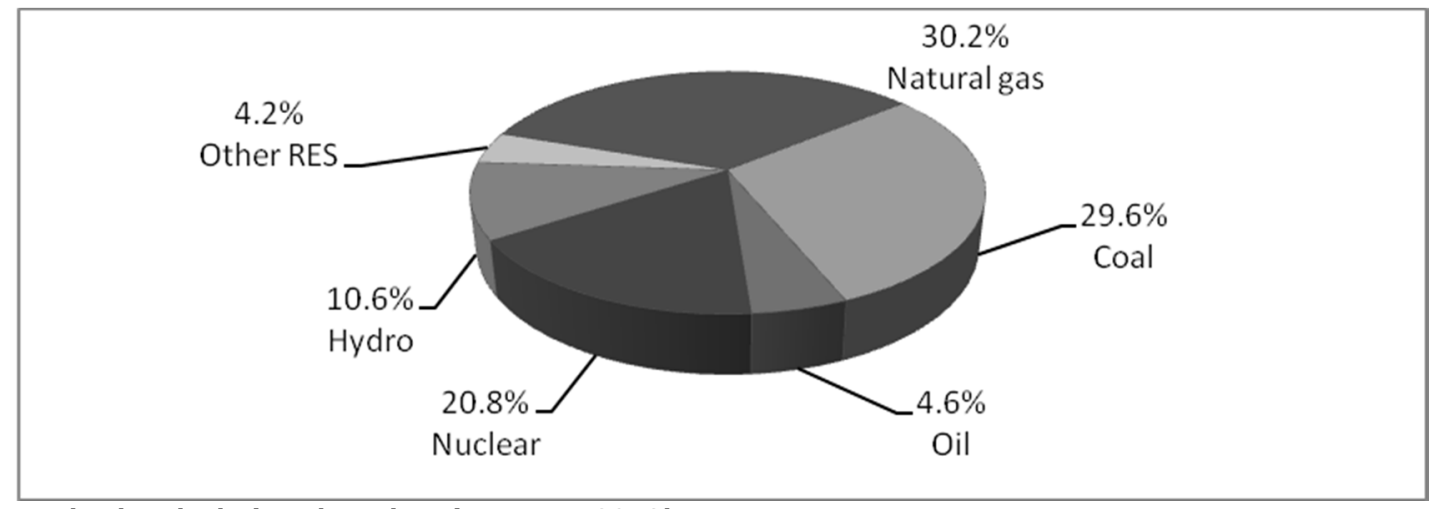

Source: author's calculations based on (Eurostat, 2018)

Fig. 2. Production of electrical energy in the European Union in 2016 (in percent)

Given the depletion of coal resources in some EU Member States, the share of coal decreased to $30 \%$ and is $11 \%$ lower compared to electrical energy mix around the world. In spite of the intention to satisfy the demand with domestic resources, which manifests itself in a higher proportion of nuclear energy and RES, the share of gas needed to guarantee energy supply in EU Member States is $9 \%$ higher than globally. As for oil and hydropower, their share is higher in the global production of electrical energy than in the EU because of countries with rich oil resources, on the one hand, and those with natural geographic conditions conducive to the constriction of hydroelectric power plants, on the other. 


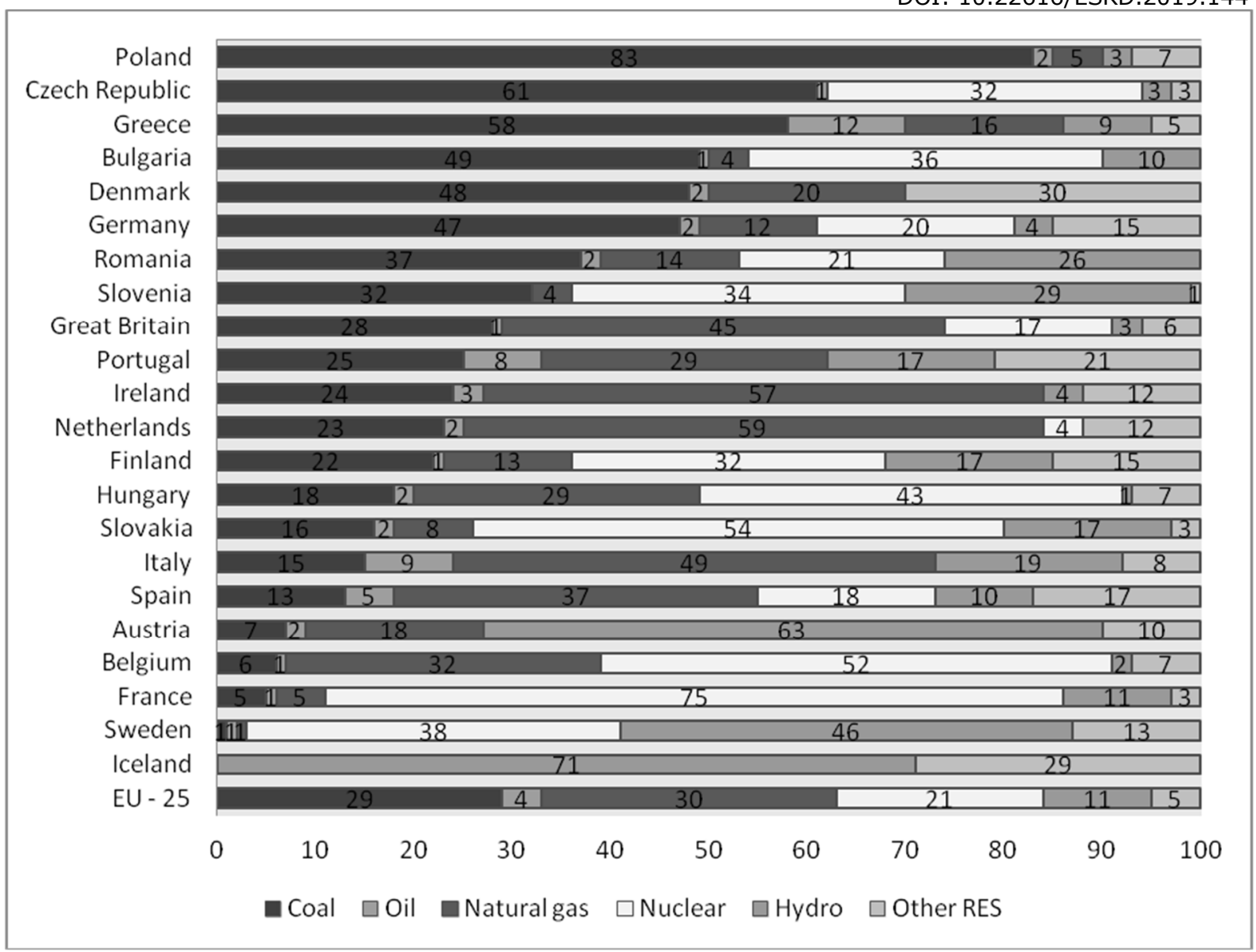

Source: author's calculations based on (Eurostat, 2018)

\section{Fig. 3. Electrical energy mix in EU Member States in 2016 (in percent)}

Figure 3 presents a detailed breakdown of electrical energy mix in individual EU countries in 2016. The average for the EU-25 is indicative of the changes concerning the main energy sources used for the production of electrical energy. Coal was replaced by gas at the top of the list, which means that the EU is now dependent on external supplies of this resource. It is possible to define the energy situation and strategy of particular countries in by analysing the energy resources used for the production of energy. For instance, many EU countries, due to the depletion of coal resources and the intention to use domestic resources without being reliant on external gas suppliers, opt for developing nuclear energy. These countries include: France (75 \%), Lithuania (76 \%), Slovakia (54\%), Belgium (52\%), Hungary (43\%), Sweden (38\%), and even Bulgaria (36\%), the Czech Republic (35\%), Slovenia (34\%) and Finland (32\%). Favourable natural conditions in Iceland and Austria allow for producing most of the energy in hydroelectric power plants, $71 \%$ and $63 \%$ respectively. Great Britain and Denmark have rich resources of gas and oil and countries such as Italy, Greece or Portugal do not produce nuclear energy due to lack of public support. Germany is currently moving away from nuclear energy because of concerns caused by the nuclear catastrophe in Fukushima, Japan, and replaces it with coal and RES. In spite of significant investments in RES, their share in electrical energy production in the EU-25 is only $5 \%$ of. An analysis of the energy situation in Germany, which is mainly responsible for the direction of the current EU climate and energy policy, indicates there are many conflicts which can lead to abandoning EU objectives altogether. In spite of numerous controversies, at the last moment the government of Germany adopted an operating program, whose aim is to lower $\mathrm{CO}_{2}$ emissions according to EU arrangements. However, when adopting the program, Barbara Hendricks (SPD), Federal Minister for the 
Environment, Nature Conservation, Building and Nuclear Safety, came to the conclusion that it would not be implemented due to the plan to abolish nuclear energy altogether, which will translate into a true renaissance of coal power plants. In the upcoming years, Germany - the global leader in brown coal mining - will produce over 50 \% of electrical energy from this resource. This is why Poland, with its coal reserves, should also opt for coal and increase its extraction so that it can be exported to EU Member States, which currently increase their imports of this resource from non-EU countries (Stepien and Miciula, 2016).

Given the vast reserves of gas in Great Britain and Denmark, and convenient access to external markets, countries such as Ireland, the Netherlands, Belgium, Italy, Spain and Portugal opt for gas as the main energy resource. However, it should be noted that gas, similarly to other main energy resources, is characterised by high emissions of greenhouse gases, as presented in Figure 4 . New coal and gas technologies such as $\mathrm{CCGT}^{1}$ and $\mathrm{CCS}^{2}$ significantly contribute to a decrease in greenhouse gas emissions down to values similar to those associated with RES. This shows that the technology used for production and consumption, which affects efficiency, availability, emissions and financial costs, is of great importance in terms of selecting a source of energy (Balitskiy, Bilan and Strielkowski, 2014). Since there is a possibility of using various technologies, double bars in the Figure below correspond to minimum and maximum emissions for different plant constructions.

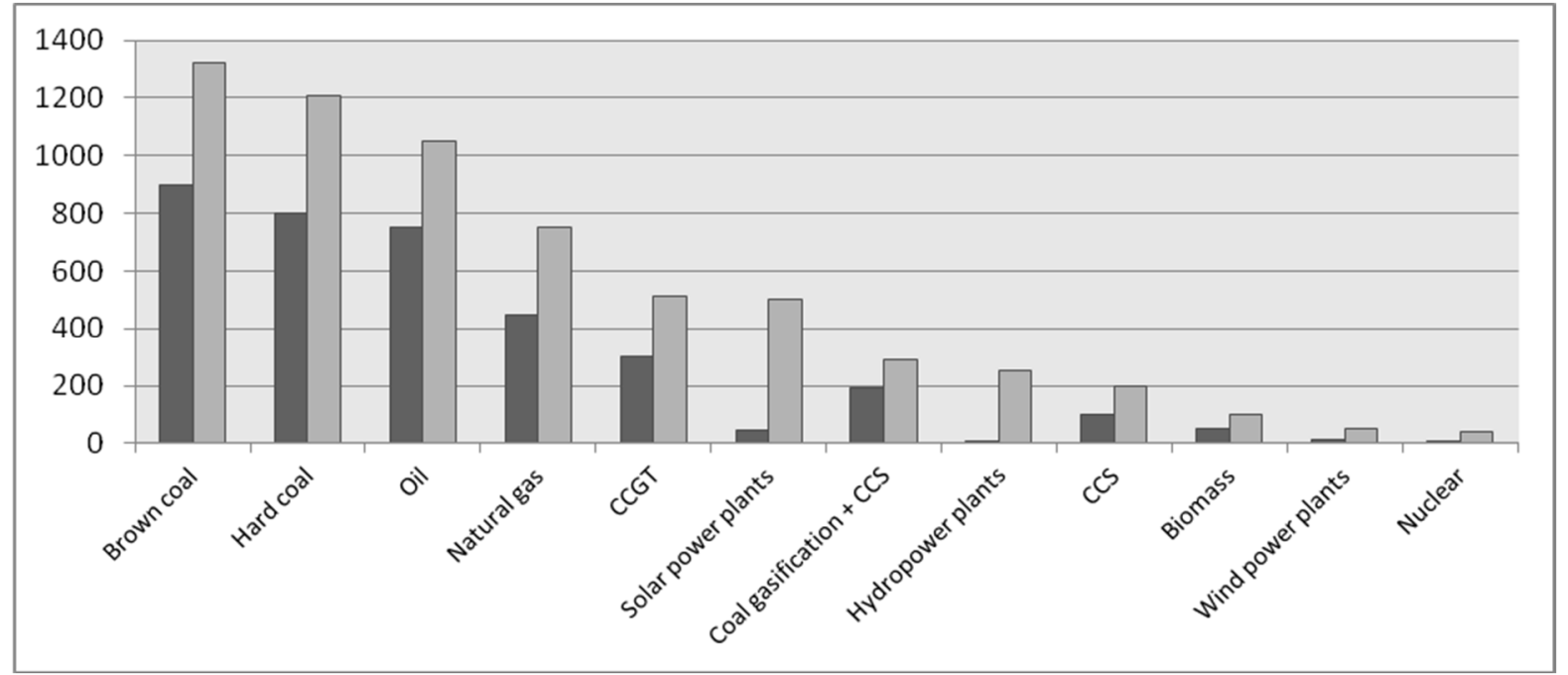

Source: author's calculations based on (International Atomic Energy Agency, 2018)

Fig. 4. Greenhouse gas emissions by energy sources (grams per $\mathbf{k W h}$ )

Forecasts indicate that the 21st century will see the beginning of diversification and due to the emergence of new technological possibilities, a new energy mix for operating machines and devices will be created. However, this will be a slow-paced process, because of the oil lobby hindering the development of alternative fuels. The second reason is the decrease in oil prices on the market resulting from the increasing extraction in Russia and the USA, where the ban on export is becoming less pronounced, and in Africa and North America, which at the same time caused a decrease in the share of OPEC in the global oil market from $50 \%$ to $30 \%$.

When analysing emissions in individual economies, the share of EU's emissions in the global $\mathrm{CO}_{2}$ emissions should be taken into account. The data below (Figure 5) clearly indicate that, although Germany ranks sixth in terms of global $\mathrm{CO}_{2}$ emissions, the entire EU does not have a significant impact on global emissions. This is why measures whose aim is to reduce $\mathrm{CO}_{2}$ emissions in $\mathrm{EU}$ Member States will not make any difference to global warming. The Figure 5 presents $\mathrm{CO}_{2}$ emissions 
for individual economies, with the percentage of global emissions in brackets. The first eight countries account for $60 \%$ of global carbon dioxide emissions. Responsible for $2.9 \%$ of global emissions, Germany is the only EU country in the global top ten. Great Britain ranks second in the EU and fourteenth worldwide, with a $1.4 \%$ share in emissions. Emissions generated by Poland constitute less than $1 \%$ on the global market. Increasing energy effectiveness is an important tool in lowering $\mathrm{CO}_{2}$ emissions, whose effects can be verified with the use of indicators demonstrating the ratio of emissions to GDP or to the population of a given country. However, as with many other indicators, detailed analyses must be performed in order to draw the right conclusions.

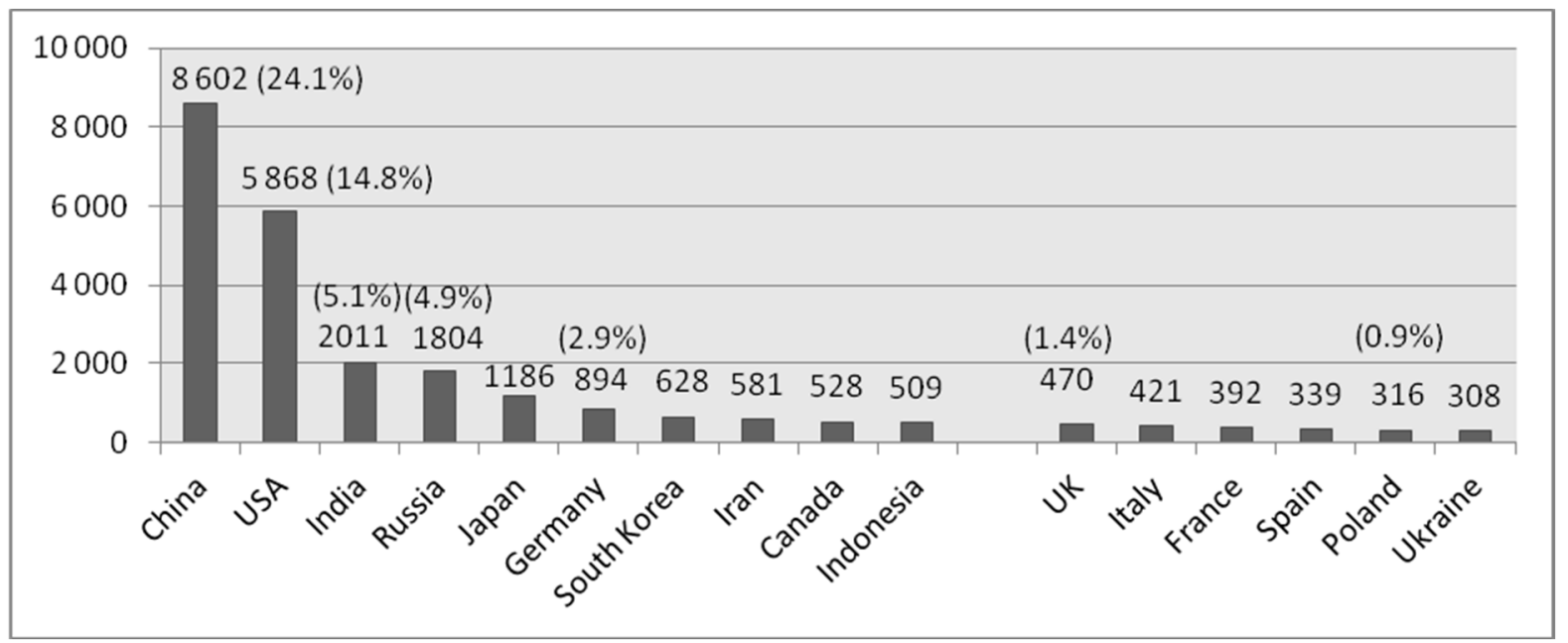

Source: author's calculations based on (BP Statistical Review of World Energy, 2017)

\section{Fig. 5. $\mathrm{CO}_{2}$ emissions in top 10 and selected countries in 2016 (in millions of $\mathbf{M g}^{1}$ )}

Given the above analysis, there is No doubt that the EU energy and climate policy will have to be changed and the period from 2020 to 2030, i.e. the time when the majority of instruments will have been in place and achievement of goals will have been verified, will be pivotal in determining whether there will be a complete overhaul of the policy. Future goals should be based on specific statistical data and indicators to accommodate all major objectives included in the so-called triad of objectives to guarantee long term, safe and predicTable framework for investment in further development of diversified sources of energy according to market rules and having regard to protection of the natural environment.

In the context of limited reserves of conventional resources in the majority of EU Member States, the EU needs to tackle two major problems: lack of energy safety and dependence on external suppliers, especially on a single supplier, e.g. Russia. At the same time, competitiveness is one of EU objectives as it would allow for lowering costs of energy production. Unfortunately, this is often contrary to the intention of becoming independent from external supplies as the cost of imported resources is lower than that of domestic sources. Therefore, in order for the policy to be coherent, priorities need to be determined. First, energy safety should be ensured, i.e. a particular country should have the necessary amount of energy at market prices (competitiveness) and only then should it pursue its own production objectives, provided that there is an economic justification for that. Especially that the energy market is undergoing constant changes and there is a tendency to create a market where the actual prices are those that charged at the moment of purchasing energy, as opposed to those specified in long-term contracts, which will be conducive to creating a market based on economic rules. Therefore, projects involving new sources of supply, new routes for transfer of 
resources, and energy source diversification are implemented so that financial aspects will become decisive (The Economist, 2013).

The below (Figure 6 and Figure 7) analysis concerns resources which satisfy a given country's demand for energy in $80 \%$, i.e. solid fuels, oil and gas. In spite of increasing dependence on external supplies, the situation in the EU varies from country to country. Denmark, the major oil and gas exporter in the EU, is completely independent in terms of energy because of its rich natural reserves of these resources. The country has also the biggest share in the production of wind energy in the EU. It only imports solid fuels because it is financially beneficial. Great Britain also has access to oil and gas resources from the bottom of the North Sea, so it only imports solid fuels, which means that its dependence on import is as low as 10 \%. Countries such as Poland, the Czech Republic, Estonia, Romania, Bulgaria, Slovenia, Greece and Germany have natural reserves of solid fuels, mainly coal, and therefore they are more independent in this respect than other EU countries, whose dependence on imports of solid fuels exceeds $90 \%$.

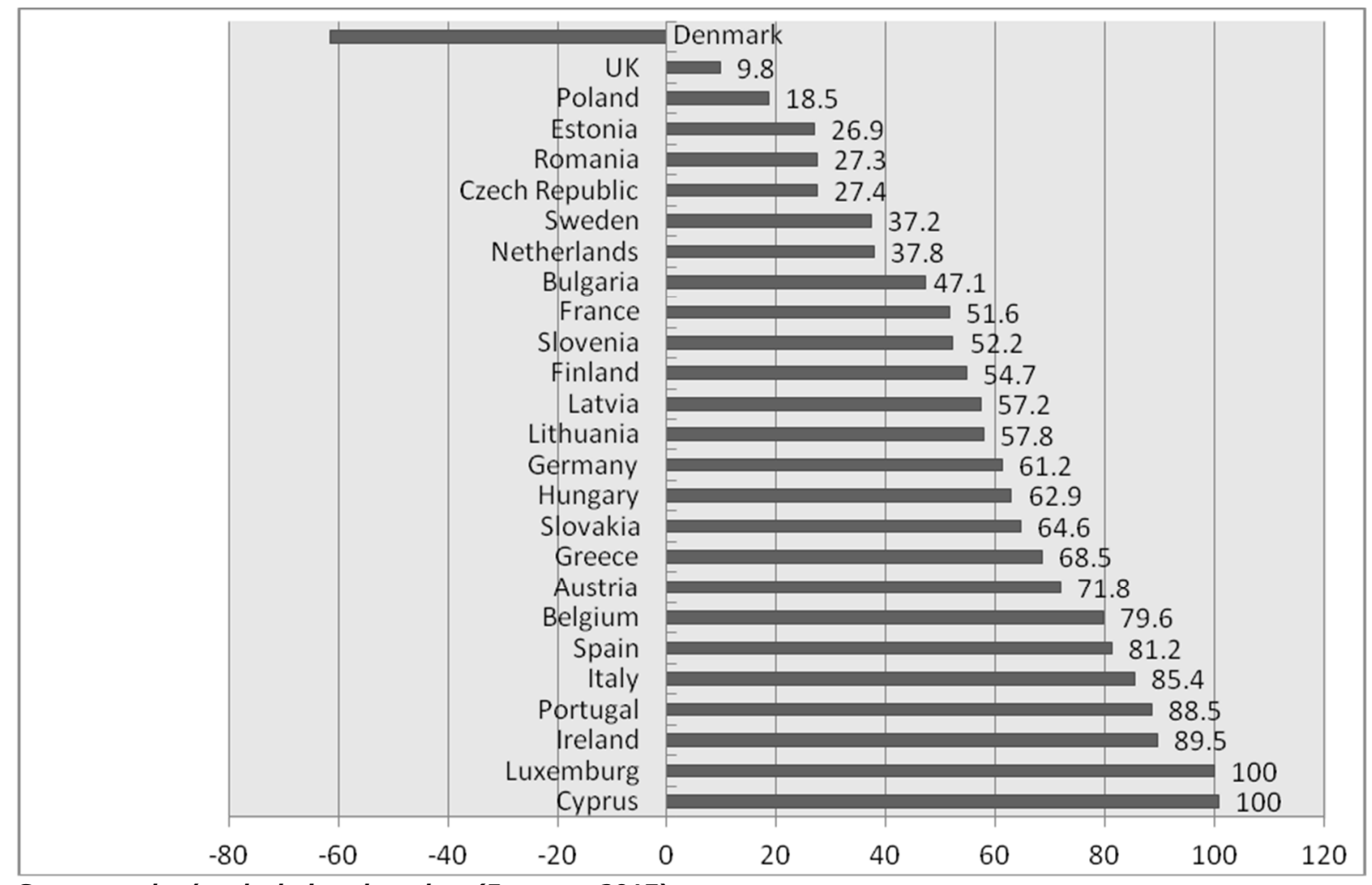

Source: author's calculations based on (Eurostat, 2017)

Fig. 6. Dependence of EU countries on imports of conventional fuels in 2015 (in percent) 


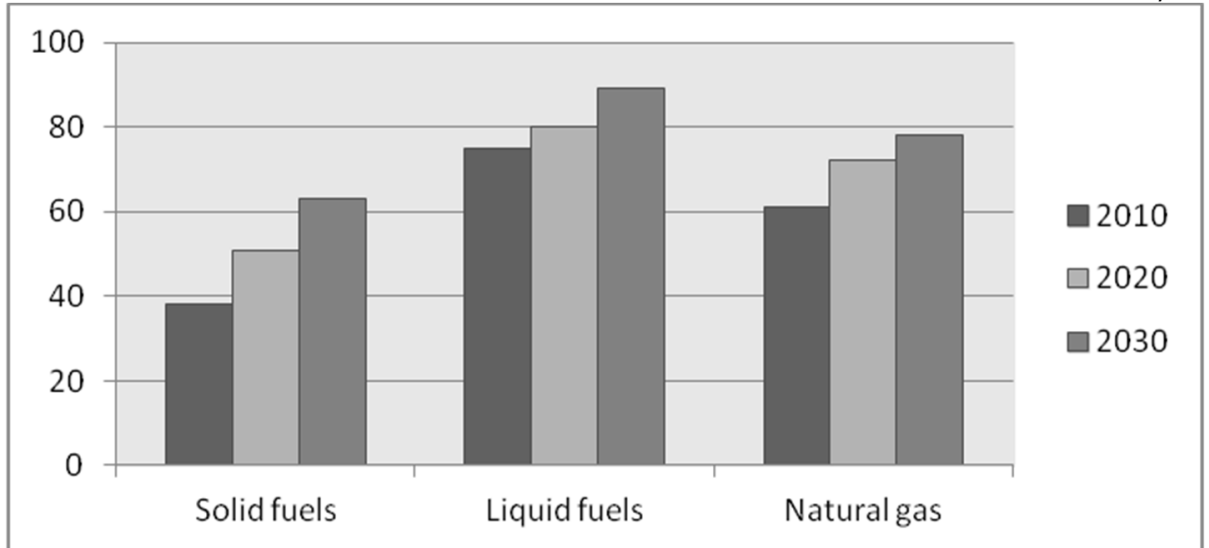

Source: author's calculations based on (European Commission, 2010)

Fig. 7. Share of imported fuels in total demand for energy products in the EU-25 and the forecast by the European Commission for the years 2020 and 2030 (in percent)

Given the current state of technology, the global promotion of RES seems paradoxical because energy management in practice shows there is No justification for the use of RES when it is not profiTable (Miciula and Miciula, 2014). Moreover, the analysis demonstrates that the use of RES is not particularly conducive to climate protection for several reasons, namely: combustion of biomass and deforestation account for $10 \%$ of greenhouse gas emissions, and smaller surface of forests means less $\mathrm{CO}_{2}$ purification. Moreover, transporting biomass also causes emission of $\mathrm{CO}_{2}$ to the atmosphere. Due to the current conditions, regulations implemented by the EU and financial reasons, there has been an increase in biomass transportation, which in turn increases $\mathrm{CO}_{2}$ emissions. The chart below (Figure 8) presents progress in reaching the targets for to the share of renewable energy in total consumption of energy, which are to be met by 2020.

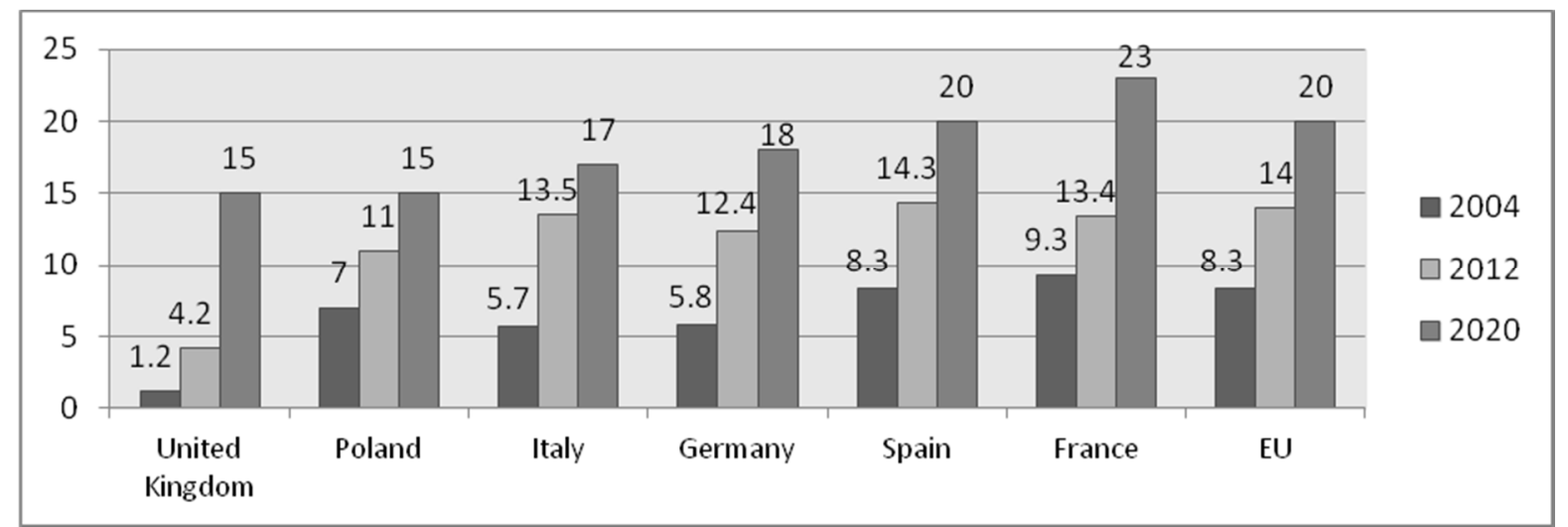

Source: author's calculations based on (Eurostat, 2017)

Fig. 8. Total share of energy from RES: electricity, gas and fuel and EU target (in percent)

In 2012, the EU average was $14 \%$, so the EU would still need $6 \%$ to meet the target. However, it should be pointed out that these shares would not have been achieved if it hadn't been for EU subsidies, which means that the change is not permanent and most probably after the results have been assessed, the shares will start decreasing (Glachant, Finon and Hauteclocque, 2014). Moreover, some of the EU Member States will have problems meeting the targets and some of them will definitely not meet them, an example being the share of transport biofuels. Great Britain for instance is a country that has struggled with reaching this target.

\section{Conclusions, proposals, recommendations}

Moreover, the very fact of achieving the $20 \%$ target cannot be treated as a success. A detailed analysis of data and effects of this task points to the conclusion that the costs of achieving this objective are high and entail a number of negative phenomena and, most importantly, that the result 
is unstable. The intention to reduce $\mathrm{CO}_{2}$ emissions resulted in the introduction of subsidies for energy crops and then the obligation to co-fire biomass with fossil fuels in power plants. In practice, the $\mathrm{CO}_{2}$ balance is significantly less advantageous than what follows from theoretical calculations due to emissions during processing (production of pellets) and transportation of biomass (The Economist, 2013). Because of the insufficient supply and high prices in Europe, import of biomass from outside the EU e.g. from Africa, Asia and South America is the practical consequence of EU regulations, which undermines the benefits related to reduced emissions (Perez-Arriaga, 2014). Green policy and investments in RES lead to a number of unexpected paradoxes.

1) There is an increase in the share of "dirty" energy. For instance, German suppliers, in order to balance the costs of green energy, buy the cheapest electricity generated from brown coal. Efficiency-wise, Germany produces 30 \% of their energy from brown coal and builds new units to ensure a permanent source of electricity in the event of fluctuations in the production from renewable sources. This is the so-called paradox of energy transformation, i.e. in spite of an increase of the share of RES in energy consumption, the $\mathrm{CO}_{2}$ emission is increasing (Research Institute Agora Energiewende, 2019).

2) Energy is expensive, i.e. technologies for producing RES will remain costly for a long time. In Germany, due to such heavy investments in RES the prices of electricity are the highest in Europe and Figures show that over 300000 households are being disconnected from the grid for unpaid bills. This phenomenon is referred to as "energy poverty".

3) With some green technologies, the long-term carbon footprint is higher than that associated with old "dirty" technologies. For instance, due to the enormous number of batteries used, electric cars have a negative impact on the environment.

4) According to EU regulations, electricity generated by biomass (primarily wood) and coal co-firing is considered clean. Businesses in the energy sector have considered it a good business opportunity, so now wood is imported in large quantities from other parts of the world to the extent that new sawmills are built in North America to handle exports to Europe.

5) Strategic aspects of energy safety in the new geopolitical situation require key investments, such as the Nabucco pipeline project, whose aim is to diversify supply sources and offer market-led possibilities to select energy sources. Significance of these investments reflects the dependence on Russia, which entails lack of security and competitiveness. Therefore, what should be done is use domestic resources and gain access to the entire market.

6) Countries which are world leaders in producing energy from coal are the ones that make most investments in green technologies.

Therefore, the "3×20" plan will No longer be implemented so rigorously because it may turn out to be a pipe dream, at least when it comes to the $20 \%$ decrease in energy consumption. The demand is certainly increasing and energy efficiency does correspond to ambitious EU plans. Commissioner Oettinger said that in order to remain competitive, the European industry needs cheap energy (Oetinger, 2011). Renewable energy sources are expensive, unsTable and require major investments in energy systems, especially in transmission grids. Therefore, while coal reserves are being depleted, many EU countries decide to develop nuclear energy, which is already the dominant source of energy in some of them.

\section{Bibliography}

1. Balitskiy, S., Bilan, Y., Strielkowski, W., (2014). Energy Security and Economic Growth in the European Union, Journal of Security and Sustainability Issues, Vol, 4, No. 2, pp. 123-130 
2. BP Statistical Review of World Energy, (2017). Retrieved: https://www.bp.com/en/global/corporate/energyeconomics/statistical-review-of-world-energy.html Access: 14.11.2018.

3. Eurostat, Retrieved: http://ec.europa.eu/eurostat/web/energy/statistics-illustrated Access: 20.11.2018.

4. European Commission, (2010). European Energy and Transport Trends to 2030 - update 2009, Brussels: EC.

5. Glachant, J.M, Finon, D., Hauteclocque, A., (2014). Competition, Contracts and Electricity Markets - a New Perspective, Firenze: Loyola de Palacio series on European Energy Policy.

6. International Atomic Energy Agency, Retrieved: http://www.iaea.org Access: 23.10.2018

7. International Energy Agency, Key World Energy Statistics 2016, Retrieved: http://www.iea.org/publications/freepublications/publication/ Access: 22.11.2018.

8. Miciula, I., Miciula, K. (2014). Energia odnawialna i jej aspekty finansowe jako element zrownowazonego rozwoju Polski (Renewable Energy and Its Financial Aspects as an Element of Sustainable Development of Poland), Prace Naukowe Uniwersytetu Ekonomicznego we Wrocławiu, No. 330, pp. 239 - 247 (Scientific Works of the University of Economics in Wroclaw, No. 330, pp. 239 - 247).

9. Oettinger, G. (2011). UE Proposes Tough Energy Efficiency Package, Brussels: News from Business Green.

10. Perez-Arriaga, I., (2014). Regulation of the Power Sector, Firenze: Loyola de Palacio series on European Energy Policy.

11. Research Institute Agora Energiewende, Retrieved: http://www.agora-energiewende.de/Paradox.pdf Access: 21.01.2019.

12.Stepien, P., Miciula, I., (2016). Liberalization of the Polish energy market and the EU commitments, Czech Journal of Social Sciences, Business and Economics, vol. 5 (2), no. 25.

13. The Economist, (2013). The fuel of the future: Environmental lunacy in Europe, Retrieved: http://www.economist.com/news/business/21575771-environmental-lunacy-europe-fuel-future Access: 10.02.2019.

14. World Nuclear Association, Retrieved: http://www.world-nuclear.org/ Access: 15.01.2019. 